\title{
INTERESTING NIPAWIN AREA BIRD NESTS
}

\section{Stuart Houston 863 University Drive, Saskatoon, SK S7N 0J8}

These are notes from the late Maurice G. Street, about 1961:

COMMON LOON. One nest on the muskeg slough south of Candle Lake had one young hatching, June 20, 1941. With my brother, Stanley, the two of us watched the loon drive an elk away from the flat rock on which the nest was placed. The loon's vigorous wing-flapping, splashing of water, and cries could be heard for miles.

MALLARD. I first noted the female duck with her brood of nine downy ducklings, raised on the grounds of a farmyard two miles east of Codette. I took fuel deliveries there about every ten days. Most of the ducklings survived, raised entirely on dry land. I knew of no waterbody closer than five miles.

EASTERN KINGBIRD. By 1958, I had found sixteen nests with three to five eggs, found by observing the nervous behaviour of the adult, which often dived at me. I saw a surprising variety of nest sites, in forks of trees, on horizontal branches, on the flat top of a dead tree-stub, in brush-piles, and on an unused implement, at a variety of elevations above ground. The most unusual nest was built on the ledge above the open door of a farm tool-shed, the kingbird eggs laid in a nest a pair of robins had built the week before. I reported that in Blue Jay. ${ }^{1}$

BOREAL CHICKADEE. I described three nests in Houston and Street
1959:138. All were in rotten spruce or tamarack stumps, where the wood ants had eaten away the heart of the stump. All were closer to the ground than any Black-capped cavity; my fourth Boreal nest was only a foot above ground. Each cavity was heavily felted with rabbit fur and a few feathers.

GRAY CATBIRD. Here, at the northern edge of their range, catbirds build their well-hidden nests composed of rootlets, bark and a few leaves, in chokecherry or willows. One nest contained a piece of string.

CANADA WARBLER. Seven nests were found under piles of leaves or in crevices on the sides of damp gullies and ravines. Several nests were destroyed by heavy June rains that washed down the sides of the steep banks.

CLAY-COLORED SPARROW. One Sunday afternoon I found 23 nests that contained 51 clay-colored eggs and 13 cowbird eggs, together with 17 young sparrows and one young cowbird. That day I also discovered two White-throated Sparrow nests and one each of the Blue Jay, Redeyed Vireo, Magnolia Warbler, Slatecolored Junco, and Fox Sparrow.

BREWER'S BLACKBIRD. Brewer's Blackbirds increased as land was cleared of poplars. They favoured "grubbed land" after the trees had been pushed over, but before the advance of the plow. Equal numbers were in low trees and on the ground. 
COMMON GRACKLE. Nests are found in brush-piles, on bridge girders, and around buildings, but most are in willow clumps near water. One nest had seven eggs.

\section{Notes from CS. Houston:}

"The provincial government has leased land in the Maurice Street Wildlife Sanctuary to the Saskatchewan Natural History Society since 1968, five years after Phillips and optometrist Stan Riome - Phillips's camping and canoeing friend - began talking about the idea.

Joining Phillips as stewards are Doug Pegg and Rick Douslin. Both Pegg and Douslin are outdoor people. They worked as conservation officers for Saskatchewan Environment." (Figure 1)

Recently I consulted my file of unpublished nest descriptions, written by Maurice G. Street, the all-time unsurpassed finder of birds' nests in Saskatchewan - 3116 nests of 133 species plus flightless young of another 10 species, all within a short drive from Nipawin. When he and Lawrence $\mathrm{H}$. Walkinshaw, on 1946 and 1947 trips searching for the then unknown nesting area of the Whooping Crane, went birding together near Nipawin, each admitted that he had finally found another observer who had developed an equal knack for finding nests. Unlike

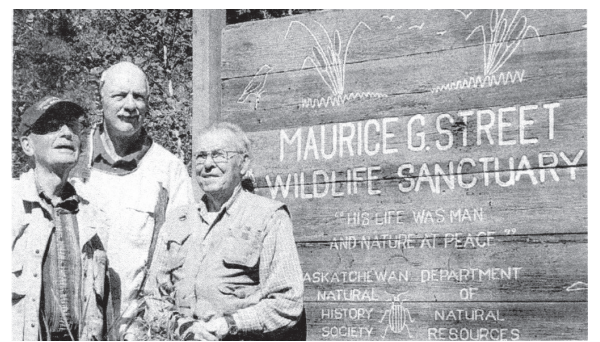

Figure 1 other oologists, who regularly took full sets of eggs, Maurice took only a single egg from the first nest he found of each species, and he did not trade eggs with other collectors. I was hoping to find descriptions of the tree species for the six Ruby-throated Hummingbird nests Street found in his lifetime near Nipawin, but that aspect of my search came up dry.

Stan Riome's diary, October 27, 1966: "Maurice Street suffered a fatal coronary thrombosis at 10 am -- death probably instant. He was found on the Imperial Oil office floor by Bruce Haywood, lying with his head in his crooked arm. This man was in intimate communion with nature, which was his God - serenity, composure, sensitivity, compassion, intelligence and unsurpassed skill caused him to be revered and respected by those very few whom he allowed to know him. My life has been enriched by his love and companionship."

Two of Maurice's friends spent an entire afternoon to find a tiny white spruce that contained a Chipping Sparrow nest, to place on his gravesite after interment. "Above all, Maurice liked a little white spruce. ${ }^{3 \text { " }}$ (Figure 2)

1. Street M (1946) Bird Notes; Eastern Kingbird. Blue Jay 5(1) p2.

\section{Houston CS (1966) Maurice G.} Street. Blue Jay 24 (4)158-159, 168.

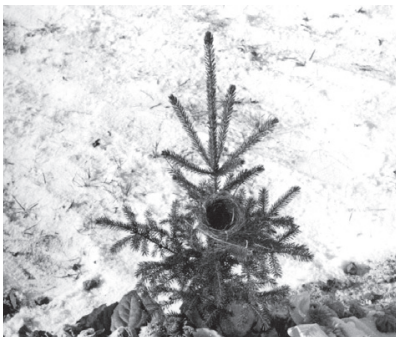

Figure 2 